\title{
PENGEMBANGAN KECERDASAN EMOSIONAL BAGI SISWA KELAS AWAL MADRASAH IBTIDAIYYAH PADA PEMBELAJARAN BAHASA INDONESIA
}

\author{
Rozib Sulistiyo \\ Kepala MI al-Islam Tonoboyo, Magelang \\ Mahasiswa Program Magister Pendidikan Islam \\ Pasca Sarjana UIN Sunan Kalijaga Yogyakarta \\ mitonoboyo@gmail.com
}

\begin{abstract}
In order to reinforce the importance of emotional development students in the early MI class were studied in the literature about the use of story methods in learning Indonesian language. Some attitudes and behaviors can be developed in strengthening the EQ of early grade MI students. For this reason, teachers are advised to use the surrounding environment as a learning media that is contextual during their stories on Indonesian language subjects.

Keywords: emotional intelligence, the initial class of MI, Indonesian language

abstrak: Guna mempertegas arti penting pengembangan emosional siswa kelas awal MI dikaji dalam literature tentang pemanfaatan metode cerita dalam pembelajaran Bahasa Indonesia. Beberapa sikap dan perilaku dapat dikembangkan dalam penguatan EQ siswa MI kelas awal. Untuk itu guru disarankan memanfaatkan lingkungan sekitar sebagai media pembelajaran yang bersifat kontekstual selama berkisah pada mata pelajaran bahasa Indonesia.
\end{abstract}

Kata kunci: kecerdasan emosional, kelas awal MI, bahasa Indonesia

\section{A. Pendahuluan}

Dewasa ini kecerdasan emosional atau Emotional Quotient (EQ) anak mulai telah memasuki fase pengembangan setelah banyak kajian yang memperkuat arti pentingnya bagi masa depan. Mubaayid menegaskasn bahwa EQ telah terbukti secara ilmiah memegang peranan penting dalam mencapai keberhasilan di segala bidang. ${ }^{1}$

Pionirnya, Coleman, mengemukakan kecerdasan intelektual (IQ) hanya menyumbang $20 \%$ bagi kesuksesan sedangkan $80 \%$ adalah sumbangan faktor kekuatan-kekuatan lain, di antaranya adalah kecerdasan emosional atau EQ, yakni kemampuan memotivasi diri sendiri, mengatasi frustasi, mengontrol desakan hati, mengatur suasana hati (mood), berempati, serta kemampuan

${ }^{1}$ Makmun Mubayidh, Kecerdasan Dan Kesehatan Emosional Anak (Depok: Pustaka Al Kautsar, 2007), h. 202. 
bekerja sama. ${ }^{2}$ Cooper dalam Mubayid juga menjelaskan bahwa hati adalah sumber keberanian dan semangat, interigitas serta komitmen. Hati adalah sumber energi dan perasaan mendalam yang menuntut kita untuk melakukan pembelajaran. 3

Di samping IQ, ada suatu jenis kecerdasan yang memegang peranan amat penting bagi kesuksesan seseorang dalam hidupnya. Hal ini ditandai dengan kemampuan seseorang anak untuk bisa menghargai dirinya sendiri maupun diri orang lain, memahamiperasaan terdalam orang -orang di sekelilingnya, mengikuti aturan - aturan yang berlaku, ini semua merupakan kunci keberhasilan bagi seoarang anak di masa depan .

Ovi Arieska dkk bahkan telah menjelaskan teori EQ dari Daniel Goleman itu tidak jauh dari perspektif pendidikan Islam, bahkan lebih mendalam. Islam telah meberikan tuntunan dalam perkembangan emosi dapat dilatih sejak anak dalam kandungan. Disitu, calon bayi sudah dapat mendengar dan merasakan. Dan oleh sebab itu, kondisi emosional ibu yang sedang hamil juga menentukan perkembangan emosi anak untuk masa yang akan datang. Kemudian pada perkembangan anak usia dini, masa dalam kandungan dikenal dengan masa prenatal, atau masa dalam kandungan. Nilai agama selanjutnya tepat pada saat anak lahir sudah dapat dilakukan yaitu dengan mengazankan dan mengiqamatkan anak yang baru lahir. Masa golden age sudah mulai sejak anak lahir.4

Oleh karena itu, Bagi siswa kelas awal madrasah ibtidaiyyah (MI), pengembangan EQ semakin terasa. Dari sisi tahapan perkembangan, Posisinya di awal-awal pendidikan dasar masih membutuhkan dorongan dan motivasi untuk bisa berdampak terhadap emosinya. Mereka masih dalam tahap perkembangan akhir periode di usia dini, kebutuhan semakin terasa. Sujud dalam Imroatun menegaskan, Sudjud mengkategorikan masa-masa awal anak memperoleh pendidikan formal itu sebagai masa strategis sekaligus kritis. Masa ini disebut strategis karena masa ini merupakan masa peka untuk memperoleh

${ }^{2}$ Daniel Goleman, Kecerdasan Emosional (Jakarta : PT Gramedia Pustaka Umum, 2000), h. 44 .

3 Ibid.

4 Ovi Arieska, Fatrica Syafri, Zubaedi," Pengembangan Kecerdasan Emosional (Emotional Quotient) Daniel Goleman Pada Anak Usia Dini Dalam Tinjauan Pendidikan Islam," Al Fitrah, Journal Of Early Childhood Islamic Education, Vol.1 No.2 Januari 2018, h. 103-116 


\section{Pengembangan Kecerdasan Emosional Bagi Siswa Kelas Awal MI Pada Pembelajaran Bahasa Indonesia}

keberhasilan dalam kehidupannya dan dikatakan masa kritis apabila tidak memperoleh stimulan dan perlakuan yang tepat, maka perkembangan anak tersendat dan tidak sesuai tahapan perkembangannya.5

Di kesempatan lain, Imroatun juga menegaskan berdasar penjelasan Mansur. ${ }^{6}$ Karena keunikan dalam pertumbuhan dan perkembangannya, periode anak usia dini terbagai dalam empat bagian, yaitu: (1) masa bayi lahir sampai 12 bulan, (2) masa toddler (batita) usia 1-3 tahun, (3) masa prasekolah usia 3-6 tahun, dan (4) masa kelas awal SD 6-8 tahun.

Dari sisi kelembagaan, MI setingkat dengan sekolah dasar namun berciri agama Islam. Kekhasan tersebut perlu ditekankan. Para guru kelas perlu memperhatikan aspek kesabaran dalam emosi anak sesuai tuntunan Quran seperti dalam al-Ahqaf [46]: 35 yang berbunyi;7

Maka bersabarlah kamu seperti orang-orang yang mempunyai keteguhan hati dari rasul-rasul telah bersabar dan janganlah kamu meminta disegerakan (azab) bagi mereka. Pada hari mereka melihat azab yang diancamkan kepada mereka (merasa) seolaholah tidak tinggal (di dunia) melainkan sesaat pada siang hari. (Inilah) suatu pelajaran yang cukup,maka tidak dibinasakan melainkan kaum yang fasik.

Dalam pembelajaran bahasa Indonesia di kelas awal MI, maka seyogyanya tetap konsisten dalam pengembangan EQ anak. Bahasa Indonesia adalah identitas kebangaan yang tidak dibisa ditinggalkan dan harus dikuasai oleh warganya termasuk yang muslim. Siswa MI menjadi bagian dari keharusan itu. Mata pelajarannya menjadi sarana pengembangan EQ Islam yang menumbuhkan semangat persatuan kebangsaan.

Melalui kajian literature dirumuskan tentang alternative pengembangan EQ melalui pembelajaran Bahasa Indonesia. Metode pentingnya berkaitan dengan cerita dan kisah sehingga bisa menjadi cara yang harus digali lebih dalam. Dengan demikian tujuan pembelajaran bisa dicapai.

5 Imroatun, "Bermain Sebagai Metode Pembelajaran Utama Anak Raudhatul Athfal” așșibyan, Jurnal Pendidikan Guru Raudlatul Athfal Vol.1, No.1, Tahun 2016, h. 40-48; Setiani dan Difla Nadjih, "Pembentukan Karakter Anak Usia Dini Melalui Pendidikan Agama Islam" Jurnal Ulumuddin Volume 6, Nomor 2, Desember 2016, h. 124-135.

6 Imroatun,”Alternatif Media Pengembangan Literasi Baca Tulis Berbahasa Nasional bagi Siswa Raudlatul Athfal” Al Hikmah Proceedings on Islamic Early Childhood Education, Volume 1, April 2018, h. 103-112.

7 Mubayidh, Kecerdasan Dan, h. 202 


\section{B. Kecerdasan Emosi}

1. Pengertian

Definisi kecerdasan emosi menurut Salovey \& Mayer adalah himpunan bagian dari kecerdasan sosial yang melibatkan kemampuan memantau perasaan dan emosi baik pada diri sendiri maupun pada orang lain, memilah milah semuanya, dan menggunakan informasi ini untuk membimbing pikiran dan tindakan. 8

Bagi Goleman,9 EQ adalah kemampuan seseorang mengatur kehidupan emosinya dengan inteligensi; menjaga keselarasan emosi dan pengungkapannya melalui keterampilan kesadaran diri, pengendalian diri, motivasi diri, empati dan keterampilan social. Robert \& Cooper mengungkapkan kemampuan dalam merasakan, memahami dan secara efektif menerapkan daya dan kepekaan emosi sebagai sumber energi, emosi, koneksi dan pengaruh yang manusiawi. Individu yang mampu memahami emosi individu lain, dapat bersikap dan mengambil keputusan dengan tepat tanpa menimbulkan dampak yang merugikan kedua belah pihak. Emosi dapat timbul setiap kali individu mendapatkan rangsangan yang dapat mempengaruhi kondisi jiwa dan menimbulkan gejolak dari dalam. Emosi yang dikelola dengan baik dapat dimanfaatkan untuk mendukung keberhasilan dalam berbagai bidang karena pada waktu emosi muncul, individu memiliki energi lebih dan mampu mempengaruhi individu lain. Segala sesuatu yang dihasilkan emosi tersebut bila dimanfaatkan dengan benar dapat diterapkan sebagai sumber energi yang diperlukan untuk menyelesaikan tugas mempengaruhi orang lain dan menciptakan hal-hal baru. ${ }^{10}$

EQ dapat diubah dan diperbaiki karena emosi bersifat tidak tetap, pasang dan surut dalam waktu singkat. Banyak orang yang beranggapan perkembangan emosi anak berjalan dengan sendirinya alias tidak perlu distimulasi Akibatnya anak jadi tidak kenal emosi dirinya hingga akhirnya tidak bisa berempati

8 Lawrence E. Shapiro, Mengajarkan EQ pada Anak (Jakarta: Gramedia Pustaka Utama, 2003), h.8

9 Goleman, Kecerdasan Emosional

${ }^{10}$ Kadeni, "Pentingnya Kecerdasan Emosional Dalam Pembelajaran" Equilibrium, Jurnal Ilmiah Ekonomi dan Pembelajarannya, Vol 2, No 1 (2014) 
kepada emosi orang lain, sering marah dengan teman atau orang disekitarnya, padahal seharusnya tidak terjadi jika anak bersabar.

2. Aspek

Ciri - ciri anak yang berkembang emosinya Salovey \& Mayer dapat dilihat kualitas emosionalnya. Kualitas itu adalah; empati, Mengungkap dan memahami perasaan, mengendalikan amarah, kemandirian, kemampuan menyesuaikan diri, disukai, kemampuan memecahkan masalah antar pribadi, Ketekunan, setia kawan, ramah, dan hormat. ${ }^{11}$

EQ memiliki lima wilayah yang meliputi : ${ }^{12}$

a. Kemampuan mengenali Emosi Diri, kemampuan seseorang dalam mengenali perasaanya sendiri sewaktu perasaan atau emosi itu muncul.

b. Kemampuan Mengelola Emosi, kemampuan seseorang untuk mengendalikan perasaanya sendiri sehingga tidak meledak dan akhirnya dapat mempengaruhi perilakunya secara salah.

c. Kemampuan Memotivasi Diri, kemampuan untuk memberikan semangat kepada diri sendiri untuk melakukan sesuatu yang baik dan bermanfaat.

d. Kemampuan Mengenali Emosi Orang Lain, kemampuan untuk mengerti perasaan dan kebutuhan orang lain, sehinngga orang lain merasa senang dan dimengerti perasaanya.

e. Kemampuan Membina Hubungan, kemampuan untuk mengelola emosi orang lain, sehingga tercipta ketrampilan sosial yang tinggi dan membuat pergaulan seseorang menjadi lebih luas.

Dalam Pendidikan Anak usia dini di Indonesia, Peraturan Menteri Pendidikan Nasional Republi Indonesia No.58 Tahun 2009 Tentang Standar Pendidikan Anak Usia Dini telah menjabarkan kelima EQ. Penjelasannya adalah sebagi berikut. ${ }^{13}$

a. Kemampuam Mengenali emosi diri, yaitu; Meminta perhatian dengan mengangkat tangan; Membuat permintaan verbal; Menolak sesuatu yang tidak nyaman bagi dirinya; Mengadukan masalah kepada orang dewasa

${ }^{11}$ Shapiro, Mengajarkan EQ pada Anak, h. 5

12 Mulyadi, Mengoptimalkan Kecerdasan.

13 Peraturan Menteri Pendidikan Nasional Republi Indonesia No.58 Tahun 2009 Tentang Standar Pendidikan Anak Usia Dini. 


\section{Rozib Sulistiyo}

ketika mengalami ketidaknyamanan dengan teman; Memilih Teman atau kegiatan sendiri

b. Kemampuan Mengelola Emosi, yaitu; Mampu berpisah dengan orang tuanya tanpa menangis; Dapat dibujuk jika menangis; Menunjukan ekspresi emosi ketika mengalami ketidaknyamanan; Menunjukan ekspresi emosi ketika mengalami kegembiraan; Sabar menunggu giliran.

c. Kemampuan memotivasi diri, yaitu; Memiliki sikap gigih / tidak mudah menyerah; Menunjukan sikap mandiri dalam memilih kegiatan; Menunjukan antusiasme dalam melakukan permainan; Menaati aturan yang berlaku dalam suatu permainan; Menolong dirinya sendiri( makan, minum, kegiatn toile

d. Mengenali emosi orang lain yaitu: Menunjukan sikap toleran, Menunjukan rasa empati dan perhatian terhadap teman, Menghargai keunggulan orang lain,Meminta izin jika menggunakan benda milik orang lain, Menolong teman yang membutuhkan

e. Kemampuan Membina Hubungan, yaitu; Senang bermain dengan teman, Mau bekerja dalam kelompok, Berkomonikasi dengan orang-orang yang ditemuinya, Mau menyapa teman yang baru dikenalnya, Bersikap kooperatif dengan teman

Beberapa aspek emosional yang biasa pada anak perlu dihindari. Aspek itu biasa tumbuh sesuai dengan lingkungannya seperti aspek yang lain. Diantaranya ada dalam penjabarannya sebagai berikut.

a. Rendah Diri

Rendah diri merupakan kondisi psikis yang menghantui sebagian anak karena cacat fisik, penyakit, factor- factor pendidikan atau karena factor ekonomi. Munculnya perasaan rendah diri pada sebagian anak antar lain adalah: Dicerca dan dihina, dimanja secara berlebihan, cacat fisik, keyatiman, kemiskinan.

b. Egois

Egois adalah sikap yang mau menang sendiri tidak peduli dengan orang lain. Perilaku seperti ini tidaklah baik apalagi jika terbawa sampai besar. Sifat seperti ini akan tidak mempunyai teman dan akan mengganggu pergaulanya nanti. Agar anak tidak egois: Biasakan anak untuk berkata maaf bila menyakiti 
teman,berbuat salah,dan berterimakasih bila menerima sesuatu dari oranglain, ketika melihat temanya jatuh dan menangis ajarkan untuk mendekatdan membantu anak tersebut,dengan cara ini anakdapat membayangkan dirinya ketika ia sendiri yang jatuh/ empati, ajarkan anak untuk berbagi dengan temanya.

c. Agresif

Perilaku agresif ini biasanya diwujudkan dengan penyerangan terhadap temannya. Penyebab prilaku ini ada dua faktor yaitu; faktor psikologis dan faktor lingkungan keluarga. Faktor psikplogis yang menjadi perilaku agresif antara lain, adalah dorongan dalam diri anak untuk mencari identitias diri dan balajar mandiri. Cara untuk menghadapi anak agresif dengan mencari penyebab mengapa anak berperilaku agresif. Bisa saja pengaruh dari menonton televisi atau factor keluarga.

d. Pemalu

Pemalu merupakan salah satu bagian dari EQ, sifat pemalu ini jika terbawa sampai besar akan berakibat tidak baik. Anak cenderung lebih banyak diam dan tidak mau berinteraksi dengan orang lain di lingkunganya. Dia ragu ragu, segan, takut, tidak berani mengambil resiko, tidak mudah percaya dan tidak mudah melibatkan diri dengan orang lain. Penyebab rasa malu bisa saja orang tua yang terlalu melindungi anak dan memanjakanya, sehingga anak menjadi pemalu dan sangat bergantung pada orang tua, di samping itu lingkungan juga berpengaruh besar dalam memperbesar sifat malu atau sebaliknya, anak kecil yang sering bergaul dengan orang lain dan berkumpul bersama mereka, rasa malu akan lebih sedikit dibanding dengan anak - anak yang kurang dan jarang berkumpul satu sama lain.

Penyebab pemalu bisa juga timbul karena orang tua tidak memberikan cukup perhatian. Sebab lain anak menjadi pemalu karena sering diejek, mendapatkan hukuman, dikritik, untuk mengatasi rasa malu pada anak ini sebaiknya orang tua atau pendidik sering mengajak berkumpul dengan orang banyak, baik mengunjungi kerabat dan teman sejawat atau menyuruhnya dengan lembut berbicara dengan orang lain baik di hadapan orang dewasa ataupun di hadapan anak - anak sebaya.

e. Marah. 
Anak pada usia balita mulai menuntut ini dan itu. Jika keinginannya tidak dipenuhi maka anak akan mengamuk. Untuk mengatasi rasa marah pada anak orang tua atau pendidik harus menjadi contoh tauladan bagi anak tentang bagaimana mengekpresikan kemarahanya yang dapat diterima oleh lingkungan. Ajarkan pada anak mengekpresikan diri dengan baik. Beberapa hal yang harus dilakukan orang tua atau pendidik bila anak marah antara lain beri tanggung jawab, ingatkan dampak prilakunya, ajarkan kontrol emosi dan hargai usahanya.

Disini dapat kita simpulkan betapa pentingnya kecerdasan emosional dikembangkan pada diri anak. Karena betapa banyak kita jumpai anak-anak, dimana mereka begitu cerdas di sekolah, begitu cemerlang prestasi akademiknya, namun bila tidak dapat mengelola emosinya, seperti mudah marah, mudah putus asa atau angkuh dan sombong, maka prestasi tersebut tidak akan banyak bermanfaat untuk dirinya. Ternyata kecerdasan emosional perlu lebih dihargai dan dikembangkan pada anak sejak usia dini. Karena hal inilah yang mendasari ketrampilan seseorang di tengah masyarakat kelak, sehingga akan membuat seluruh potensinya dapat berkembang secara lebih optimal.

\section{EQ dan pembelajaran bahasa Indonesia}

Bagi siswa belajar bahasa Indonesia memiliki manfaat yang sesuai dengan perannya. Peran bahasa persatuan di Republik Indonnesia itu dijabarkan oleh Kartadinata. ${ }^{14}$

1. Bahasa Nasional, lambang kebanggaan dan identitas nasional, Bahasa persatuan kita, memiliki nilai-nilai sosial budaya luhur bangsa yang harus dipertahankan dan direalisasikan dalam kehidupan sehari-hari tanpa ada rasa renda diri, malu, dan acuh tak acuh. Indonesia memiliki banyak budaya dan bahasa yang berbeda-beda hampir di setiap daerah. Pastinya, tidak akan mungkin kita bisa saling memahami ketika berkomunikasi antar sesama. Oleh karena itulah betapa pentingnya kedudukan bahasa indonesia sebagai bahasa pemersatu bangsa dan sebagai alat penghubungan antarbudaya dan daerah.

14 Sunaryo Kartadinata, Panduan Pengajar Buku Inovasi Pendidikan (Jakarta: Depdikbud, 2000), h. 6 


\section{Pengembangan Kecerdasan Emosional Bagi Siswa Kelas Awal MI Pada Pembelajaran Bahasa Indonesia}

2. Bahasa Negara, fungsinya adalah bahasa dalam perhubungan pada tingkat nasional untuk kepentinganperencanaan dan pelaksanaan pembangunan serta menjadi bahasa resmi kenegaraan, pengantar di lembaga-lembaga pendidikan/ pemanfaatan ilmu pengetahuan, pengembangan kebudayaan, pemerintah dll.

3. Alat Untuk Mengembangkan Ilmu Pengetahuan. Tanpa adanya bahasa, IPTEK tidak dapat tumbuh dan berkembang. Selain itu bahasa Indonesia di dalam struktur budaya, ternyata memiliki kedudukan, fungsi, dan peran ganda, yaitu sebagai akar dan produk budaya yang sekaligus berfungsi sebagai sarana berpikir dan sarana pendukung pertumbuhan dan perkembangan ilmu pengetahuan dan teknologi. Tanpa peran bahasa serupa itu, ilmu pengetahuan dan teknologi tidak akan dapat berkembang. Implikasinya di dalam pengembangan daya nalar, menjadikan bahasa sebagai prasarana berpikir

Adapun Pelajaran bahasa Indonesia untuk MI dan yang sederajat memiliki tujuan antara lain, yaitu: ${ }^{15}$

1. berkomunikasi secara efektif dan efisien sesuai dengan etika yang berlaku baik secara lisan maupun tulis;

2. menghargai dan bangga menggunakan bahasa Indonesia sebagai bahasa persatuan dan bahasa negara;

3. memahami bahasa Indonesia dan menggunakannya dengan tepat dan kreatif untuk berbagai tujuan;

4. menggunakan bahasa Indonesia untuk meningkatkan kemampuan intelektual serta kematangan emosional dan sosial;

5. menikmati dan memanfaatkan karya sastra untuk memperluas wawasan, memperhalus budi pekerti, meningkatkan pengetahuan dan kemampuan berbahasa; dan

6. menghargai dan membanggakan sastra Indonesia sebagai khasanah budaya dan intelektual manusia Indonesia.

15 Eko Nurdiyanti \& Edy Suryanto, "Pembelajaran Literasi Mata Pelajaran Bahasa Indonesia Pada Siswa Kelas V Sekolah Dasar" Paedagogia, Jilid 13, Nomor 2, Agustus 2010, $h$. $115-128$ 
Pembelajaran bercerita telah diakui secara ilmiah memberikan dampak bagi pengembangan bahasa Indonesia. Salah satunya adaalah penelitian dari Wigita dkk. Pembelajaran berbicara dengan menggunakan metode becerita dapat mempengaruhi keterampilan berbicara pada murid kelas IV SD Negeri Mangkura 4 Makassar Kecamatan Ujung Pandang, Kelurahan Sawerigading, Kota Makassar, Sulawesi Selatan.

Di situ, Metode bercerita dapat meningkatkan aktivitas pembelajaran yang ditunjukkan dengan beberapa aspek, yaitu murid bersemangat untuk membaca cerita yang dipilihkan oleh guru. Murid memperhatikan contoh guru bercerita. Murid berani bertanya jawab yang berhubungan dengan cerita. Murid menuliskan unsur-unsur cerita dan membacakannya di depan kelas. Murid berlatih bercerita dengan kelompoknya, membaca dua sampai tiga kali cerita untuk memahami karakter setiap tokoh. Murid antusias untuk maju bercerita. Murid menyimak teman yang lain saat bercerita. Murid berani bercerita di depan kelas dengan penuh kesungguhan. Murid menyimpulkan cerita yang telah disampaikan. Murid berani mengekspresikan perasaan mereka setelah bercerita. Hasil penelitian yang dilaksanakan kelas IV SD Negeri Mangkura 4 Makassar Kecamatan Ujung Pandang, Kelurahan Sawerigading, Kota Makassar, Sulawesi Selatan menunjukan jika metode bercerita dan keterampilan berbicara saling berpengaruh dalam hasil belajar dan aktivitas belajar murid. ${ }^{16}$

Darmila dkk. kemudian mengutip Rahayu yang menegaskan kisah lisan mendukung anak-anak untuk belajar membaca, memahami pengetahuan dunia, dan menjadikan sosial-emosi baik. Selain itu bercerita juga merupakan kegiatan yang dilakukan seseorang secara lisan kepada orang lain dengan alat atau tanpa alat tentang apa yang harus disampaikan dalam bentuk pesan, informasi, atau dongeng untuk didengarkan dengan rasa yang menyenangkan. ${ }^{17}$

16 Tamara Wigita, Hambali, Andi Adam, "Pengaruh Metode Bercerita Terhadap Keterampilan Berbicara Pada Pembelajaran Bahasa Indonesia Kelas IV SD Negeri Mangkura IV Makassar” JKPD Jurnal Kajian Pendidikan Dasar, Vol 1, No 2 (2016): (Juli 2016)

17 Lilis Darmila, Humaidah Br, Hasibuan, Nunzairina, "Pengaruh Metode Bercerita Terhadap Perkembangan Kokakata Anak Usia 5-6 Tahun Di RA Hajjah Siti Syarifah Kecamatan Medan Tembung” Jurnal Raudhah, Vol. o6 No. o1, Januari-Juni 2018. 


\section{Pengembangan Kecerdasan Emosional Bagi Siswa Kelas Awal MI Pada Pembelajaran Bahasa Indonesia}

Biar manfaat bercerita bermanfaat dalam EQ selama pembelajaran sepatutnya guru bisa mempertimbangkan beberapa kondisi pembelajaran yang berpotensi terjadi dalama kelas. Hal itu telah diutarakan oleh Nurbiana dkk. ${ }^{18}$,

1. Cerita Dapat menjangkau jumlah anak yang relatif banyak,

2. Waktu yang tersedia selam bercerita dapat dimanfaatkan dengan efektif dan efisien,

3. Pengaturan kelas menjadi lebih sederhana,

4. Guru dapat menguasai kelas dengan mudah,

5. Secara relatif tidak banyak memerlukan biaya,

6. Anak didik menjadi pasif, karena lebih banyak mendengarkan atau menerima cerita dari guru,

7. Kurang merangsang perkembangan kreativitas dan kemampuan siswa untuk mengutarakan pendapatnya,

8. Daya serap atau daya tangkap anak didik berbeda dan masih lemah sehingga sukar dipahami tujuan pokok isi cerita,

9. Cepat menumbuhkan rasa bosan terutama apabila penyajiannya tidak menarik.

Dari sisi materi cerita juga memerlukan perhatian. Perangsangan EQ melalui cerita seharusnya memenuhi hal-hal sebagai berikut;19

1. Dunia kehidupan anak yang penuh suka cita, yang menuntut isi cerita memiliki unsur yang dapat memberikan perasaan gembira, lucu, menarik, dan mengasyikan bagi anak;

2. Disesuaikan dengan minat anak yang biasanya berkenaan dengan binatang, tanaman, kendaraan, boneka, robot, planet, dan lain sebagainya;

3. Tingkat usia, kebutuhan dan kemampuan anak menangkap isi cerita berbeda-beda. Maka cerita yang harapkan haruslah bersifat ringkas atau pendek dalam rentang perhatian anak;

4. membuka kesempatan bagi anak untuk bertanya dan menanggapi setelah guru selesai bercerita.

18 Dhieni Nurbiana dkk. Metode Pengembanga Bahasa (Jakarta: UniversitasTerbuka, 2013), h. 48 
Fitriya kemudian mengusulkan strategi pengembangan EQ. strategi itu bisa digunakan selama berkisah dalam belajar bahasa Indonesia pada kelas Awal MI. ${ }^{20}$

1. Menyadari emosi anak. orangtua harus menyadari ketika sedang merasakan emosi anak, mengidentifikasi perasaan perasaan anak, dan peka pada perasaan atau emosi pada diri anak. Dengan menyadari emosi anak, kecerdasan emosional anak akan terlatih karena anak merasa dihargai sehingga dengan begitu anak juga akan bisa mengenal dan menyadari emosi yang terjadi pada dirinya.

2. Mendengarkan dengan penuh empati dan meneguhkan perasaan anak tersebut; yaitu mendengarkan dan mengamati petunjuk-petunjuk fisik emosi pada anak. Orang tua menggunakan imajinasi mereka untuk melihat situasi tersebut dari titik pandang anak kemudian menggunakan kata-kata mereka untuk merumuskan kembali dengan cara yang menenangkan dan tidak mengecam untuk menolong anak-anak mereka memberi nama emosiemosi mereka itu.

3. Menganggap emosi anak sebagai suatu kesempatan untuk akrab dan mendidik.

4. Membantu anak untuk menyebutkan emosi anak secara verbal. Terkadang oleh karena kemampuan diferensiasinya masih rendah, anak sering kesulitan memberi nama terhadap emosinya sendiri, apakah dia sedang merasa sedih, jengkel atau bosan. Maka dari itu orangtua penting untuk membantu anak untuk menyebut emosi anak secara verbal.

5. Menghindari kritik berlebihan, komentar menghina atau mentertawa-kan. Strategi menghindari kritik yang berlebihan sangat penting karena anak yang terlalu sering disalahkan cenderung menyebabkan yang bersangkutan mengalami sindrom "takut salah" yaitu keadaan dimana anak akan terlalu sering menanyakan hampir setiap perilaku yang akan dilakukannya kepada orangtua/orang dewasa lain yang dihormatinya. Dengan adanya menghindari kritik yang berlebihan dan komentar menghina dan 
mentertawakan maka anak akan tumbuh lebih percaya diri, menghargai perasaannya dan perasaan orang lain.

6. Memberikan pujian terhadap anak. Pujian diberikan ketika anak dapat mengenal dan mengekspresikan dengan benar sesuai batas-batas yang dapat diterima oleh masyarakatnya.

7. Memberikan pilihan dan menghormati keinginan anak. Cara ini mendorong anak memiliki rasa percaya diri yang cukup untuk berani mengambil keputusan.

\section{Penutup}

Selama berkisah dalam belajar bahasa Indonesia beberapa sikap dan perilaku dapat muncul dan bisa dipertimbangkan dan diasah bagi pengembangan EQ siswa MI kelas awal. Diantaranya pemberian informasi atau menanamkan nilai-nilai sosial, moral dan keagamaan, pemberian informasi tentang lingkungan fisik dan lingkungan sosial. Lainnya, anak bisa menyerap pesan-pesan yang dituturkan. Ia pun mampu mendengarkan dengan seksama terhadap apa yang disampaikan oleh guru dan orang lain. Ia menjadi berani untuk bertanya apabila tidak memahaminya. Sebaliknya, dapat menjawab pertanyaan. Akhirnya, anak bisa bercerita kembali maupun mengekspresikan apa yang didengarkan dan diceritakannya, sehingga hikmah dari isi cerita dapat dipahami dilaksanakan dan diceritakannya pada orang lain.

Dari sisi pengembangan bahasa, bercerita, anak memiliki kemampuan menyimak, berbicara serta menambah jumlah kosa kata yang dikuasai. Untuk itu guru kelas awal MI dalam pembelajaran bahasa Indonesia melalui bercerita dapat memaksimalkan kegiatan dengan memanfaatkan media pembelajaran yang tersedia serta dalam mengeksplorasi lingkungan sekitar sebagai media pembelajaran yang bersifat kontekstual.

\section{Daftar Pustaka}

Darmila, Lilis, Humaidah Br, Hasibuan, Nunzairina. "Pengaruh Metode Bercerita Terhadap Perkembangan Kokakata Anak Usia 5-6 Tahun Di RA Hajjah Siti Syarifah Kecamatan Medan Tembung." Jurnal Raudhah, Vol. o6 No. O1, Januari-Juni 2018,

Dhieni Nurbiana dkk. Metode Pengembangan Bahasa. Jakarta: UniversitasTerbuka, 2006

Fatihah, Nurul \& Difla Nadjih. "Hubungan Pendidik Dan Terdidik Dalam AlQuran, Jurnal Ulumuddin Volume 7, Nomor 2, Desember 2017," 74-97 
Fitriya, Anita. "Optimalisasi perkembangan Kecerdasan Emosional (EQ) Anak Usia Dini.” Al Qodiri : Journal of Education, Social and Religious, Vol 14 No 1 (2018): April, 1-15

Goleman, Daniel Kecerdasan Emosional. Jakarta : PT Gramedia Pustaka Umum, 2000.

Imroatun, Imroatun. "Bermain Sebagai Metode Pembelajaran Utama Anak Raudhatul Athfal," as-sibyan, Jurnal Pendidikan Guru Raudlatul Athfal Vol.1, No.1, Tahun 2016, h. 40-48

Imroatun, Imroatun."Alternatif Media Pengembangan Literasi Baca Tulis Berbahasa Nasional bagi Siswa Raudlatul Athfal," Al Hikmah Proceedings on Islamic Early Childhood Education, Volume 1, April 2018, h. 103-112

Kadeni, "Pentingnya Kecerdasan Emosional Dalam Pembelajaran," Equilibrium, Jurnal Ilmiah Ekonomi dan Pembelajarannya, Vol 2, No 1 (2014)

Kartadinata, Sunaryo. Panduan Pengajar Buku Inovasi Pendidikan. Jakarta,. Depdikbud. 2000

Latif Mukhtar dkk., Orientasi Baru Pendidikan Anak Usia Dini. Jakarta: Kencana. 2013.

Mubayidh, Makmun. Kecerdasan Dan Kesehatan Emosional Anak. Depok: Pustaka Al Kautsar,2007.

Nurdiyanti, Eko \& Suryanto, Edy. "Pembelajaran Literasi Mata Pelajaran Bahasa Indonesia Pada Siswa Kelas V Sekolah Dasar.” PAEDAGOGIA, Jilid 13, Nomor 2, Agustus 2010, h. 115-128

Ovi Arieska, Fatrica Syafri, Zubaedi."Pengembangan Kecerdasan Emosional (Emotional Quotient) Daniel Goleman Pada Anak Usia Dini Dalam Tinjauan Pendidikan Islam. Al Fitrah, Journal Of Early Childhood Islamic Education, Vol.1 No.2 Januari 2018, h. 103-116

Peraturan Menteri Pendidikan Nasional Republi Indonesia No.58 Tahun 2009 Tentang Standar Pendidikan Anak Usia Dini.

Rahman, Hibana S. Konsep Dasar PAUD. Yogyakarta: PGTKI Press, 2008.

Setiani dan Difla Nadjih, "Pembentukan Karakter Anak Usia Dini Melalui Pendidikan Agama Islam," Jurnal Ulumuddin Volume 6, Nomor 2, Desember 2016, h. 124-135.

Shapiro, Lawrence E. Mengajarkan EQ Pada Anak. Jakarta: Gramedia Pustaka Utama, 2003

Wigita, Tamara Hambali, Andi Adam. "Pengaruh Metode Bercerita Terhadap Keterampilan Berbicara Pada Pembelajaran Bahasa Indonesia Kelas IV SD Negeri Mangkura IV Makassar.” JKPD Jurnal Kajian Pendidikan Dasar, Vol 1, No 2 (2016): (Juli 2016) 